PREGLEDNI NAUČNI ČLANAK

\title{
Dragana Pejović*
}

\section{PROSTITUCIJA U UPOREDNOM PRAVU I PRAVU REPUBLIKE SRBIJE}

\begin{abstract}
Apstrakt: U 2016. godini stupio je na snagu Zakon o javnom redu i miru koji je doneo novinu kada je u pitanju regulisanje prostitucije u Republici Srbiji. Pored osoba koje se odaju prostituciji, a koje su najčešće žene, osoba koje ustupaju prostorije radi prostitucije, ovim zakonom propisuje se i prekršajno sankcionisanje korisnika usluga prostitucije. Predmet analize u ovom radu je zakonsko regulisanje prostitucije u Republici Srbiji. Normativnom metodom analiziraće se odredbe Zakona o javnom redu $i$ miru Republike Srbije kojima se reguliše prostitucija, kao i odredbe medunarodnih dokumenata koji su relevantni kada je u pitanju regulisanje prostitucije. Glavni cilj istraživanja je da se ustanovi da li je Republika Srbija regulisala prostituciju u skladu sa medunarodnim dokumentima i aktuelnim modelima zakonskog regulisanja prostitucije u državama članicama EU. Rezultati istraživanja pokazuju da je u Republici Srbiji još uvek na snazi prohibicionistički model čije represivne mere najviše pogađaju žene koje se bave prostitucijom. Rezultati na polju suzbijanja prostitucije mogu se postići jedino izmenom postojećeg modela tako što će mere protiv prostitucije biti uperene ka korisnicima seksualnih usluga.
\end{abstract}

Ključne reči: međunarodni dokumenti, prostitucija, Zakon o javnom redu i miru Republike Srbije, zakonsko regulisanje prostitucije, žene u prostituciji.

\section{UVODNA RAZMATRANJA}

U Republici Srbiji su do stupanja na snagu aktuelnog Zakona o javnom redu i miru ${ }^{1}$ izvršioci prekršaja prostitucije bile osobe koje se odaju prostituciji, osobe koje ustupaju prostorije radi prostitucije, ali ne i korisnici usluga prostitucije. Kako se prostitucijom bave prevashodno žene, a

* Advokatkinja u Novom Sadu i doktorantkinja Centra za rodne studije, Asocijacija centara za interdisciplinarne i multidisciplinarne studije i istraživanja (ACIMSI), Univerzitet u Novom Sadu e-mail: adv.dragana.pejovic@gmail.com

1 Zakon o javnom redu i miru, Sl. glasnik RS, br. 6/16. 
kao korisnici se pojavljuju pretežno muškarci, žene su bile te koje je pogađao teret prekršajnog sankcionisanja, dok su muškarci bili oslobođeni bilo kakve odgovornosti za učestvovanje u prostituciji. Zakon o javnom redu i miru, koji je stupio na snagu 2016. godine, zadržao je prohibicionistički model regulisanja prostitucije, sa tom razlikom što su i korisnici usluga prostitucije izvršioci prekršaja. ${ }^{2}$ Novčana i kazna zatvora su propisane $u$ istoj visini za sve učesnike u prostituciji.

Ne menjajući prohibicionistički sistem regulisanja prostitucije, zakonodavac je ostao pri stavu da se represivnim merama učesnici u prostituciji mogu odvratiti od učestvovanja u prostituciji. Pobornici prohibicionističkog modela ostavljaju po strani uzroke koji utiču na obim prostitucije, verujući da će se kažnjavanjem žena koje se bave prostitucijom ili svih učesnika u prostituciji postići pozitivni efekti na planu suzbijanja prostitucije. Krajnji cilj prohibicionističkog modela regulisanja prostitucije je iskorenjivanje prostitucije kao negativne društvene pojave.

\section{Regulisanje PROSTITUCiJe U MEĐUNARODNIM DOKUMENTIMA}

Prostitucija nije posebno regulisana jednim međunarodnim dokumentom. Među državama ne postoji na međunarodnom nivou opšteprihvaćena definicija prostitucije odraslih osoba. ${ }^{3}$ Razlog za navedeno stanje je nemogućnost postizanja konsenzusa među državama o načinu regulisanja prostitucije na međunarodnom nivou. Iz navedenih razloga države samostalno regulišu prostituciju odraslih u okviru svog nacionalnog zakonodavstva. ${ }^{4}$

Uprkos navedenom, u mnogobrojnim dokumentima Ujedinjenih nacija, Saveta Evrope i Evropske unije kojima je regulisana trgovina ljudima u cilju seksualne eksploatacije i nasilje nad ženama sadržane su odredbe koje se direktno ili indirektno odnose i na prostituciju.

Žene u prostituciji predstavljaju vulnerabilnu grupu kada su u pitanju trgovci ljudima, dok nasilje predstavlja jedan od bitnih uzroka ulaska

2 Član 16. ZJRM, Sl. glasnik RS, br. 6/16.

3 „Dečija prostitucija podrazumeva korišćenje dece u seksualnim aktivnostima za novčanu ili bilo koju drugu naknadu." - član 2. stav 1. tačka 6. Zakona o potvrđivanju Fakultativnog protokola o prodaji dece, dečijoj prostituciji i dečijoj pornografiji uz Konvenciju o pravima deteta, Sl. list SRJ - Medunarodni ugovori, br. 7/02.

4 Shulze E., Novo Canto, S. I., Mason, P., Skalin, M., 2014, Sexual exploitation and prostitution and its impact on gender equality, p. 69 (http://www.europarl.europa.eu/ RegData/etudes/etudes/join/2014/493040/IPOL-FEMM_ET(2014)493040_EN.pdf, 12.08.2016). 
žena u prostituciju ${ }^{5}$, a zatim postaje i sastavni deo života žena koje se bave prostitucijom, zbog čega se odredbe ovih dokumenata mogu posredno dovesti u vezu sa prostitucijom. Posebno je značajno što je u ovim međunarodnim dokumentima, iako neposredno ne regulišu prostituciju, prepoznato da prostitucija i trgovina ljudima u cilju seksualne eksploatacije nesrazmerno pogađaju žene i devojčice, odnosno prepoznato je da obe pojave pripadaju rodnoj problematici. ${ }^{6} 7$

Konvencija o suzbijanju trgovine ljudima i eksploatacije prostitucije drugih iz 1949. godine ${ }^{8}$ predstavlja prvi pravno obavezujući dokument $\mathrm{u}$ kom se spominje veza između prostitucije i trgovine ljudima u svrhu prostitucije. U Preambuli se konstatuje da su prostitucija i trgovina ljudima u cilju prostitucije nespojivi sa dostojanstvom i vrednošću ljudske ličnosti. Poseban značaj Konvencije je što se u njoj promoviše abolicionistički pristup u regulisanju prostitucije u skladu sa kojim žene u prostituciji ne podležu sankcionisanju. ${ }^{9}$ Konvencijom se ukazuje da na faktore ulaska žena u prostituciju treba preventivno uticati putem obrazovnih, socijalnih, zdravstvenih i drugih ustanova. Nedostatak Konvencije je što sadrži definiciju eksploatacije prostitucije što predstavlja trgovinu ljudima, na osnovu čega se može zaključiti da se u Konvenciji ne pravi razlika između prostitucije i eksploatacije prostitucije, zbog čega je ona danas izgubila na značaju. ${ }^{10}$

Kada je reč o prisilnoj prostituciji kao jednom od oblika eksploatacije žrtava trgovine ljudima, među državama vlada nepodeljen stav da je u pitanju kršenje osnovnih ljudskih prava.

U Protokolu za prevenciju, suzbijanje i kažnjavanje trgovine ljudima, naročito ženama i decom, koji je usvojen 2000. godine kao dopuna

5 Prema istraživanjima 65-90\% žena u prostituciji je pretrpelo neki oblik seksualnog zlostavljanja u prošlosti. European Parliament resolution on the current situation in combating violence against women and any future action (2004/2220(INI)), recital M i N, (http://www.europarl.europa.eu/sides/getDoc.do?pubRef=-//EP//TEXT+TA+P6TA-2006-0038+0+DOC+XML+V0//EN, 15.08.2016).

6 Shulze E., Novo Canto, S. I., Mason, P., Skalin, M., 2014.

7 Žene su najčešće žrtve trgovine ljudima u cilju seksualne eksploatacije i čine čak $97 \%$ žrtava trgovine ljudima u cilju seksualne eksploatacije. "Global report on trafficking in persons", p. 37, (https://www.unodc.org/documents/data-and-analysis/glotip/ GLOTIP_2014_full_report.pdf, 15.08.2016).

8 Convention for the Suppression of the Traffic in Persons and of the Exploitation of the Prostitution of Others, (http://www.ohchr.org/EN/ProfessionalInterest/Pages/ TrafficInPersons.aspx, 15.05.2016).

9 Convention for the Suppression of the Traffic in Persons and of the Exploitation of the Prostitution of Others, article 6.

10 ASTRA, 2011, Trgovina ljudima u Republici Srbiji, Izveštaj za period 2000-2010, str. 63, (http://www.astra.org.rs/wp-content/uploads/2008/07/palermo-2010-SRP-web.pdf, 15.08.2016) 
Konvencije Ujedinjenih nacija protiv transnacionalnog organizovanog kriminala, ${ }^{11}$ države se obavezuju da će međusobno sarađivati u cilju ublažavanja siromaštva, nedovoljne razvijenosti i nedostataka jednakih mogućnosti kao faktora koji dovode do toga da žene i devojčice budu izložene trgovini ljudima. Navedenom odredbom ističe se postojanje nejednakih mogućnosti i siromaštva na strani žena u odnosu na muškarce. ${ }^{12}$ Mere kojima se preventivno utiče na trgovinu ljudima su obrazovne, socijalne ili kulturne i treba da budu usmerene na potražnju koja dovodi do eksploatacije ljudi, posebno žena i dece. ${ }^{13}$

Konvencija Saveta Evrope o borbi protiv trgovine ljudima koja je doneta 2005. godine ${ }^{14}$ označava potražnju kao glavni uzrok trgovine ljudima. Iz tog razloga se u ovoj konvenciji ukazuje na važnost uticanja delotvornim merama na obeshrabrivanje potražnje koja dovodi do trgovine ljudima. Države se obavezuju da u tom cilju donesu ili unaprede zakonodavne, obrazovne, socijalne i druge mere. ${ }^{15}$

U Deklaraciji o eliminaciji nasilja prema ženama ${ }^{16}$ govori se o posebnom obliku nasilja uperenom prema ženi koje se javlja u porodici a povezano je sa eksploatacijom. ${ }^{17}$ Pod ovu odredbu može se podvesti nasilje povezano sa eksploatacijom prostitucije koje se neretko dešava u okviru porodice, kada se žene prisiljavaju od strane, najčešće muških, članova porodice na bavljenje prostitucijom. ${ }^{18}$

U Preporuci o trgovini ženama i prisilnoj prostituciji u državama članicama Saveta Evrope br. $1325^{19}$ iz 1997. godine navedeno je da trgovina ženama i prisilna prostitucija predstavljaju oblik nehumanog i ponižavajućeg postupanja i flagrantno kršenje ljudskih prava. Ističe se da je porast

11 Zakon o potvrđivanju Konvencije Ujedinjenih nacija protiv transnacionalnog organizovanog kriminala i dopunskih protokola, Sl. list SRJ-Međunarodni ugovori, br. 6/01.

12 Član 9. stav 5. Zakona o potvrđivanju Konvencije Ujedinjenih nacija protiv transnacionalnog organizovanog kriminala i dopunskih protokola.

13 Član 9. stav 5. Zakona o potvrđivanju Konvencije Ujedinjenih nacija protiv transnacionalnog organizovanog kriminala i dopunskih protokola.

14 Konvencija Saveta Evrope o borbi protiv trgovine ljudima, Sl. glasnik RS - Medunarodni ugovori, br. 19/09.

15 Član 6. Konvencije Saveta Evrope o borbi protiv trgovine ljudima.

16 Declaration on the Elimination of Violence against Women, (http://www.un.org/ documents/ga/res/48/a48r104.htm, 31.08.2016).

17 Declaration on the Elimination of Violence against Women, article 2.

18 http://www.un.org/documents/ga/res/48/a48r104.htm, 31.08.2016.

Žikić, B., 2008, Rizik i nasilje, Antropološko proučavanje seksualnog rada u Beogradu, Beograd, str. 72 .

19 Recommendation 1325 (1997) Traffic in women and forced prostitution in Council of Europe member states, (http://assembly.coe.int/nw/xml/XRef/Xref-XML2HTMLen.asp?fileid=15359\&lang=en 31.08.2016). 
trgovine ženama doveo žene u položaj sličan ropstvu. ${ }^{20}$ Imajući u vidu porast trgovine ženama u cilju seksualne eksploatacije, Skupština preporučuje Komitetu ministara da izradi konvenciju o trgovini ženama i prisilnoj prostituciji koja bi bila otvorena za potpisivanje i od strane država koje nisu članice Saveta Evrope. Konvencija bi trebalo isključivo da se odnosi na odrasle žene. ${ }^{21}$

Preporukom br. R (2000) 11 Komiteta ministara državama članicama o borbi protiv trgovine ljudima u svrhu seksualne eksploatacije, ${ }^{22}$ donetoj 2000. godine, državama se savetuje da izvrše istraživanja koja će se odnositi na potražnju na koju su danas usmerene mnogobrojne mere u cilju borbe protiv trgovine ljudima ali i prostitucije. Usmeravanjem pažnje na potražnju može se zaključiti da se Preporukom zastupa abolicionistički pristup kada je u pitanju trgovina ljudima ali i prostitucija. Ukazuje se na važnost preduzimanja mera kojima će se postići dugoročni rezultati u suzbijanju trgovine ljudima u cilju seksualne eksploatacije delovanjem na ukorenjene uzroke trgovine ljudima. Kao glavni uzroci trgovine ženama navodi se socijalni i ekonomski status žena. Zbog toga dugoročne mere treba usmeriti na osnaživanje socijalnog i ekonomskog položaja žena i uzroke koji dovode do toga da žene postanu žrtve trgovine ljudima.

U Direktivi 2011/36/EU Evropskog parlamenta i Saveta donetoj 2011. godine, koja se odnosi na prevenciju i borbu protiv trgovine ljudima i zaštitu žrtava trgovine ljudima, ${ }^{23}$ ističe se važnost potrebe da se prepozna rodni aspekt trgovine ljudima te da se ženama i muškarcima ne trguje u iste svrhe. Svrha u koju se vrši eksploatacija mora se uzeti u obzir kako bi se razlikovali faktori koji podstiču ili ne podstiču lice da postane žrtva trgovine ljudima. U skladu sa tim mere podrške i pomoći treba da budu različite u zavisnosti od toga da li se trguje ljudima u cilju seksualne ili radne eksploatacije. ${ }^{24}$

20 Recommendation 1325 (1997) Traffic in women and forced prostitution in Council of Europe member states, point 1.

21 Recommendation 1325 (1997) Traffic in women and forced prostitution in Council of Europe member states, point 4.

22 Recommendation No. R(2000)11 of the Committee of Ministers to member states on action against trafficking in human beings for the purpose of sexual exploitation, (http://polis.osce.org/library/f/2686/499/CoE-FRA-RPT-2686-EN-Council\%20of\%20 Europe\%20Committee\%20of\%20Ministers\%20Recommendation\%20R(2000)\%2011. pdf, 31.08.2016).

23 Directive 2011/36/EU of the European Parliament and of the Council of 5 April 2011 on preventing and combating trafficking in human beings and protecting its victims, and replacing Council Framework Decision 2002/629/JHA, (http://eur-lex.europa. eu/legal-content/EN/TXT/PDF/?uri=CELEX:32011L0036\&from=EN 31.08.2016).

24 Directive 2011/36/EU of the European Parliament and of the Council of 5 April 2011 on preventing and combating trafficking in human beings and protecting its victims, and replacing Council Framework Decision 2002/629/JHA, recital 3. 
U Rezoluciji Evropskog parlamenta o strategijama za sprečavanje trgovine ženama i decom koja su osetljiva na seksualnu eksploataciju (2004/2215 (INI)), usvojenoj 2006. godine, ${ }^{25}$ konstatuje se da je postojanje lokalnog tržišta prostitucije na kom žene i deca mogu da se prodaju i kupuju preduslov za postojanje međunarodne trgovine ljudima. Rezolucija direktno dovodi u vezu prostituciju i trgovinu ljudima, odnosno ukazuje na vulnerabilnost žena u prostituciji kada je u pitanju trgovina ljudima $\mathrm{u}$ cilju prisilne prostitucije. ${ }^{26}$

\section{Modeli Zakonskog Regulisanja prostitucije U DRŽAVAMA EU}

Nepostojanje jedinstvenog stava na međunarodnom nivou o modelu zakonskog regulisanja prostitucije omogućilo je državama da slobodno odluče da li će i na koji način u okviru nacionalnog zakonodavstva regulisati prostituciju. Kako je trgovina ljudima u cilju seksualne eksploatacije stalni pratilac prostitucije, države odabirom modela zakonskog regulisanja prostitucije posredno biraju i način na koji će se boriti protiv trgovine ljudima u cilju seksualne eksploatacije.

Postoje tri osnovna tipa pravnog regulisanja prostitucije, $\mathrm{s}$ tim da $\mathrm{dr}$ žave odabrani model prilagođavaju svojim potrebama.

\subsection{PROHIBICIONISTIČKI MODEL REGULISANJA PROSTITUCIJE}

Prvi tip regulisanja prostitucije je prohibicionistički, za koji se opredelila Republika Srbija. U skladu sa prohibicionističkim modelom regulisanja, prostitucija je zabranjena, odnosno nelegalna delatnost. Odabirom ovog modela zakonskog regulisanja prostitucije država šalje poruku da se prostitucija smatra negativnom i nedopuštenom društvenom pojavom protiv koje se bori sankcionisanjem nekih ili svih učesnika u prostituciji. Prema Kuhajdi, država se odlučuje za prohibicionistički model regulisanja kada ima za cilj da zaštiti porodicu ali i celo društvo od prostitucije kao opasnosti u vidu nemorlane društvene pojave. ${ }^{27}$ Međutim, i

25 European Parliament resolution on strategies to prevent the trafficking of women and children who are vulnerable to sexual exploitation (2004/2216(INI)), (http:// www.europarl.europa.eu/sides/getDoc.do?pubRef=-//EP//TEXT+TA+P6-TA-20060005+0+DOC+XML+V0//EN, 31.08.2016).

26 European Parliament resolution on strategies to prevent the trafficking of women and children who are vulnerable to sexual exploitation (2004/2216(INI)), recital D.

27 Kuhajda V., 1972, Prostitucija u Vojvodini, magistarski rad, Pravni fakultet Univerziteta u Beogradu, str. 42. 
pored zabrane, prostitucija u državama koje prihvataju prohibicionistički model postoji, a negativan odnos prema prostituciji najviše pogađa žene koje se bave prostitucijom. S obzirom na to da podležu zakonskom sankcionisanju, društvo posmatra žene koje se bave prostitucijom kao delinkventkinje, dok su one istovremeno izložene fizičkom i ekonomskom nasilju makroa, policije i korisnika seksualnih usluga. Prohibicionistički model regulisanja prostitucije ima za cilj iskorenjivanje prostitucije represivnim merama, dok zanemaruje uzroke ulaska žena u prostituciju. Osim toga, nedostatak prohibicionističkog modela je što ne pruža ženama u prostituciji mogućnost izlaska iz prostitucije kroz odgovarajuće programe.

\subsection{REGLEMENTACIONI MODEL REGULISANJA PROSTITUCIJE}

Sistem reglementacije predstavlja drugi tip regulisanja prostitucije. Pobornici reglementacionog sistema insistiraju na pravljenju razlike između dobrovoljne i prisilne prostitucije, odnosno trgovine ljudima u cilju seksualne eksploatacije. ${ }^{28} \mathrm{Na}$ osnovu ovakvog razlikovanja, veruje se da će se zakonskim regulisanjem dobrovoljne prostitucije napraviti jasna razlika između prostitucije i seksualne eksploatacije. Takođe, pristalice reglementacije smatraju da država zakonskim regulisanjem prostitucije štiti i same žene koje se bave prostitucijom tako što im omogućava da uživaju prava po osnovu radnog odnosa.

Reglementacioni model regulisanja prostitucije najčešće podrazumeva osnivanje javnih kuća u okviru kojih se odvija prostitucija. Kao prednosti ovog modela navode se: mogućnost države da vrši nadzor nad prostitucijom, jednostavan i siguran način da muškarac zadovolji svoje seksualne potrebe i sprečavanje širenja polnih bolesti. ${ }^{29}$

Nasuprot navedenim prednostima, žene u javnim kućama su najčešće ekonomski eksploatisane od strane vlasnika, nemaju mogućnost da vrše selekciju klijenata, a podvrgavanje lekarskim pregledima odnosi se samo na žene, dok korisnici seksualnih usluga nemaju istu obavezu. ${ }^{30}$ Navedeni nedostaci govore u prilog diskriminatornom položaju žena koje se bave prostitucijom u reglementacionom sistemu, a koji je i bio

28 Shulze E., Novo Canto, S. I., Mason, P., Skalin, M., 2014, p. 20. http://www.europarl.europa.eu/RegData/etudes/etudes/join/2014/493040/IPOL-FEMM_ET(2014)493040_ EN.pdf, 12.08.2016.

29 Kuhajda, V., 1972, str. 37.

30 Kuhajda, V., 1972, str. 42. 
glavni razlog za jačanje abolicionističkih stavova kada je u pitanju regulisanje prostitucije.

\subsection{ABOLICIONISTIČKI MODEL REGULISANJA PROSTITUCIJE}

Abolicionistički model regulisanja prostitucije je treći tip regulisanja prostitucije koji je nastao u borbi protiv potčinjenog položaja žena koje se bave prostitucijom u reglementacionom sistemu. Abolicionistički pristup u regulisanju prostitucije je rezultat borbe za prava, odnosno „oslobođenje žena” u prostituciji ukidanjem javnih kuća. ${ }^{31}$ Države koje su prihvatile abolicionistički model regulisanja prostitucije odustaju od zakonskog regulisanja prostitucije. Pristalice abolicionizma smatraju da ovaj tip regulisanja prostitucije omogućava ženama koje žele da se bave prostitucijom da to čine svojom slobodnom voljom, sklapajući dogovor sa korisnikom bez javnih kuća ili makroa koji bi ih ekonomski eksploatisali. Uprkos navedenom, države koje su se opredelile za abolicionistički model ne regulišu zakonima prostituciju jer je smatraju nemoralnom društvenom pojavom. ${ }^{32} \mathrm{U}$ skladu sa tim shvatanjem prostitucija predstavlja prostor u kom muškarci mogu platiti seksualno zlostavljanje žena. ${ }^{33}$

$\mathrm{Na}$ temeljima abolicionizma nastao je neoabolicionizam, nov model regulisanja prostitucije koji je uvela Švedska 1999. godine, kada se opredelila za borbu protiv prostitucije sankcionisanjem kupaca seksualnih usluga. Neoabolicionisti, kao i abolicionisti, smatraju da su proklamovana osnovna ljudska prava i princip rodne ravnopravnosti u suprotnosti sa kupovinom seksualnih usluga žena od strane muškaraca. ${ }^{34}$ Pobornici neoabolicionizma prostituciju vide kao oblik nasilja prema ženama pa je iz tog razloga treba eliminisati. ${ }^{35}$ Nakon Švedske, neoabolicionistički model preuzeli su Island i Norveška, pa je sada „švedski model” prerastao u „nordijski model” regulisanja prostitucije. ${ }^{36}$

31 Danna, D., 2014, Report on prostitution laws in the European Union, p. 14, (http:// lastradainternational.org/lsidocs/3048-EU-prostitution-laws.pdf, 25.08.2016).

32 Danna, D., 2014, Report on prostitution laws in the European Union, p. 15, (http:// lastradainternational.org/lsidocs/3048-EU-prostitution-laws.pdf, 25.08.2016).

33 Shulze E., Novo Canto, S. I., Mason, P., Skalin, M., 2014, p. 19.

34 Shulze E., Novo Canto, S. I., Mason, P., Skalin, M., 2014, p. 14.

35 Shulze E., Novo Canto, S. I., Mason, P., Skalin, M., 2014, p. 16.

36 Amnesty International, 2016, The human cost of 'crushing' the market, criminalization of sex work in Norway, p. 18, (http://www.amnestyusa.org/sites/default/files/norway_ report_-_sex_workers_rights_-_embargoed_-_final.pdf, 31.08.2016). 


\subsection{PREOVLAĐUJUĆI MODELI ZAKONSKOG REGULISANJA PROSTITUCIJE U DRŽAVAMA EU}

Danas su abolicionistički i reglementacioni model regulisanja prostitucije dva najzastupljenija modela u državama članicama Evropske unije. Reglementacioni sistem zastupljen je u Holandiji, Nemačkoj, Grčkoj, Austriji, Mađarskoj i Letoniji. Države koje su prihvatile abolicionistički model su Belgija, Bugarska, Kipar, Češka Republika, Danska, Estonija, Finska, Francuska, Italija, Luksemburg, Malta, Poljska, Portugalija, Slovačka, Slovenija, Španija, Finska, Irska i Ujedinjeno Kraljevstvo. U državama u kojima je na snazi abolicionistički sistem prostitucija je dekriminalizovana, ali su podvođenje, javne kuće i druge aktivnosti u vezi sa prostitucijom zabranjene. Prostitucija je zabranjena u Rumuniji, Litvaniji i Hrvatskoj. ${ }^{37}$

Države su počele da napuštaju prohibicionistički model regulisanja prostitucije pošto je uočeno da zakonsko sankcionisanje prostitucije doprinosi povezivanju prostitucije sa drugim oblicima kriminala. ${ }^{38}$ Abolicionistički i reglementacioni tip regulisanja prostitucije, osim osnaživanja žena u prostituciji, imaju za cilj sprečavanje trgovine ljudima u cilju seksualne eksploatacije. Pobornici abolicionizma smatraju da nema razlike između dobrovoljne i prisilne prostitucije, odnosno obe pojave podvode pod seksualnu eksploataciju. Prostituciju vide kao posledicu neravnopravnog položaja žene i muškarca u društvu, nepovoljne ekonomske pozicije žene koja se posebno ogleda u višoj stopi siromaštva žena, diskriminaciji žena na tržištu rada i visokoj stopi nasilja prema ženama u društvu. ${ }^{39}$ Suprotno ovom stavu, pristalice reglementacionog tipa regulisanja prostitucije zastupaju stav da treba napraviti razliku između prisilne i dobrovoljne prostitucije, a da dobrovoljnu prostituciju treba zakonski regulisati. Zalažu se za pravo žene da samostalno i nezavisno odluči šta će činiti sa svojim telom. ${ }^{40}$ Takođe, zastupnici reglementacionog modela regulisanja prostitucije veruju da i same žene u prostituciji imaju koristi od zakonskog regulisanja prostitucije jer se poboljšavaju uslovi u kojima rade, a omogućeno im je i da nasilne klijente prijave nadležnim organima. ${ }^{41}$ Smatraju da se zakonskim regulisanjem prostitucije, odnosno stavljanjem prostitucije pod kontrolu države, osnažuju žene koje se bave prostitucijom jer prostitucija postaje legalna delatnost, pa ni žene u prostituciji više nisu marginalizovane. ${ }^{42}$

37 Shulze E., Novo Canto, S. I., Mason, P., Skalin, M., 2014, pp. 31-32.

38 Radulović, D., 1986, Prostitucija u Jugoslaviji, Beograd, str. 170.

39 Shulze E., Novo Canto, S. I., Mason, P., Skalin, M., 2014, p. 25.

40 Shulze E., Novo Canto, S. I., Mason, P., Skalin, M., 2014, p. 24.

41 Shulze E., Novo Canto, S. I., Mason, P., Skalin, M., 2014, p. 15.

42 Shulze E., Novo Canto, S. I., Mason, P., Skalin, M., 2014, p. 13. 


\section{Regulisanje prostitucije U \\ Zakonu o JaVnom Redu i miru Republike Srbije}

Zakon o javnom redu i miru, koji je stupio na snagu 2016. godine, ${ }^{43}$ doneo je izmene u kažnjavanju učesnika u prostituciji u Republici Srbiji. Novina se odnosi na kažnjavanje korisnika seksualnih usluga koji do stupanja na snagu ovog zakona nisu bili izvršioci prekršaja. ${ }^{44}$ Izvršilac prekršaja bila je osoba koja se odaje prostituciji i osoba koja ustupa prostorije radi prostitucije. ${ }^{45} \mathrm{~S}$ obzirom na to da korisnici seksualnih usluga nisu bili izvršioci prekršaja, u podređenom položaju su bile osobe koje se bave prostitucijom, odnosno žene, dok su muškarci kao najčešći korisnici seksualnih usluga ostajali nekažnjeni. Kada se analizira ovo rešenje sa rodnog aspekta, navedeni način zakonskog regulisanja prostitucije promovisao je dvostruke standarde. Žene su bile sankcionisane zbog bavljenja prostitucijom, dok su muškarci kao korisnici usluga prostitucije, svesni nekažnjivosti, posredno bili podržavani da koriste usluge žena u prostituciji.

Na prvi pogled može izgledati da su izmenom zakonskog rešenja učesnici u prostituciji konačno „jednaki” pred zakonom. U praksi je teško očekivati da će korisnici seksualnih usluga biti kažnjavani u istoj meri kao žene u prostituciji. Razlog za to treba tražiti pre svega u zakonskoj formulaciji prostitucije kao prekršaja. Prema zakonskoj odredbi, za prostituciju će biti kažnjen „ko se odaje prostituciji” i „ko koristi usluge prostitucije”. Žene u uličnoj prostituciji svoje usluge nude javno, međutim korisnici usluge prostitucije ne koriste ih javno, što otežava njihovo otkrivanje. Pored toga, sa formulacijom koja glasi „ko koristi usluge prostitucije” biće teško dokazati postojanje prekršaja, osim ako korisnik usluge prostitucije nije uhvaćen na delu.

Zakonodavac je u ovom slučaju mogao upotrebiti formulaciju kao što je „ko traži usluge prostitucije” ${ }^{6}$ zato što korisnici, bar kada je reč o uličnoj prostituciji, usluge prostitucije traže javno, što bi u praksi olakšalo državnim organima da prekšajno sankcionišu korisnike seksualnih usluga.

Prostitucija ne predstavlja opasnost po društvo u meri kao kada je reč o narkomaniji ili razbojništvima, ${ }^{47}$ zbog čega ni pripadnici Ministar-

43 ZJRM, Sl. glasnik RS, br. 6/16.

44 Član 16. stav 1. ZJRM, Sl. glasnik RS, br. 6/16.

45 Zakon o javnom redu i miru, Sl. glasnik RS, 51/92, 53/93, 67/93, 48/94, 101/05 - dr. zakon i 85/05 - dr. zakon, član 14. prestao da važi.

46 Ovakvu formulaciju sadrži član 12. stav 1. Predloga zakona o prekršajima protiv javnog reda i mira Republike Hrvatske koji je predstavljen 2012. godine (www.sabor.hr/ fgs.axd?id=21935, 18.08.2016).

47 Nikolić, Z., 2007, Prostitucija i trgovina ljudima, Zbornik Instituta za kriminološka $i$ sociološka istraživanja, 1-2, str. 105. 
stva unutrašnjih poslova nemaju motivaciju za veće angažovanje kao što je „hvatanje na delu” korisnika seksualnih usluga.

Zakon o javnom redu i miru za bavljenje prostitucijom propisuje kaznu zatvora u rasponu od 30 do 60 dana, dok je prema prethodnom Zakonu o javnom redu i miru kazna zatvora iznosila do 30 dana. Novinu predstavlja i uvedena novčana kazna za bavljenje prostitucijom koja se kreće u rasponu od 50.000,00 do 150.000,00 dinara. Ista novčana i zatvorska kazna propisana je za korisnike seksualnih usluga, kao i za osobe koje ustupaju prostorije radi prostitucije. ${ }^{48}$ Cena uobičajene seksualne usluge ${ }^{49}$ u uličnoj prostituciji iznosi $1.000,00-1.500,00$ dinara $^{50}$ na osnovu čega se može zaključiti da žene u prostituciji neće moći da plate visoke iznose propisanih novčanih kazni. Prekršajni sudovi će novčanu kaznu pretvarati u zatvorsku kaznu, što će samo dodatno nepovoljno uticati na život žena koje se bave prostitucijom. Odlazak u zatvor, osim što je traumatično iskustvo za žene koje se bave prostitucijom, ${ }^{51}$ proizvodi i finansijski gubitak koji one, nakon izlaska iz zatvora, moraju da nadoknade. ${ }^{52}$

Posredovanje u prostituciji predstavlja krivično delo pod koje se podvode radnje navođenje ili podsticanje nekog lica na prostituciju ili učestvovanje u predaji nekog lica drugom licu radi vršenja prostitucije, propagiranje ili reklamiranje prostitucije putem sredstava javnog informisanja ili drugih sličnih sredstava. Propisana zatvorska kazna kreće se u rasponu od šest meseci do pet godina. ${ }^{53}$

$\mathrm{Na}$ osnovu pooštrene kaznene politike u Zakonu o javnom redu i miru nedvosmisleno se može zaključiti da je zakonodavac ostao pri uverenju da se prohibicionističkim modelom regulisanja prostitucije može postići uspeh u suzbijanju prostitucije, iako je ovaj model regulisanja prostitucije u evropskim državama skoro potpuno napušten zbog svoje neefikasnosti.

Kažnjavanje žena u prostituciji do sada nije dalo rezultate na polju prevencije u Republici Srbiji ako se ima u vidu podatak da $80 \%$ žena kažnjenih zbog bavljenja prostitucijom čine povratnice. ${ }^{54}$ Visok procenat žena koje se

48 Član 16. stav 1. ZJRM, Sl. glasnik RS, br. 6/16.

49 Uobičajena seksualna usluga podrazumeva polni odnos ili oralni seks.

50 Žikić, B., 2008, str. 113-114.

51 Na osnovu intervjua urađenih sa ženama koje se bave prostitucijom, Žikić zaključuje da one boravak u zatvoru smatraju kao vrstu nasilja nad njihovom profesijom. Žene u prostituciji ne razumeju iz kojih razloga se one tretiraju kao osobe koje izvrše razbojništva, ubistva ili druga teška krivična dela. Žikić, B., 2008, str. 186.

52 Žikić, B., 2008, str. 187.

53 Član 184. stav 1. Krivičnog zakonika, Sl. glasnik RS, br. 85/05, 88/05 - isp., 72/09, 111/09, 121/12, 104/13 i 108/14.

54 Stojaković, G., Petrović-Ranitović T., 2013, Prostitucija u Srbiji: jedno od mogućih lica, Novi Sad, str. 52. 
višestruko kažnjavaju zbog prostitucije takođe ukazuje na to da je potrebno promeniti pristup u zakonskom regulisanju prostitucije i pružiti ženama u prostituciji odgovarajuće programe za izlazak iz prostitucije.

\section{ZAKLJUČAK}

$\mathrm{Na}$ osnovu analize odredaba međunarodnih dokumenata koje se mogu dovesti u vezu sa prostitucijom, može se zaključiti da zakonodavac prilikom regulisanja prostitucije u Zakonu o javnom redu i miru nije uzeo u obzir da je u svim međunarodnim dokumentima potražnja za komercijalnim seksom označena kao glavni faktor koji utiče na porast prostitucije. Suprotno međunarodnim dokumentima, u skladu sa odredbama Zakona o javnom redu i miru svi učesnici u prostituciji podjednako snose odgovornost za učestvovanje u prostituciji. Imajući u vidu način zakonskog formulisanja prostitucije kao prekršaja i dosadašnju praksu kažnjavanja žena u prostituciji, one će i ubuduće snositi sav teret prekršajnog sankcionisanja prostitucije.

Zakonodavac prilikom regulisanja prostitucije nije uzeo u obzir da prostituciju izazivaju socijalni faktori, što se izričito navodi u svim međunarodnim dokumentima koji se mogu dovesti u vezu sa prostitucijom. Kažnjavanjem žena u prostituciji ne utiče se na socijalne faktore koji opredeljuju obim prostitucije, a koji ostaju van domašaja prohibicionističkog modela regulisanja prostitucije. Pozitivni rezultati u suzbijanju prostitucije mogu se postići samo ukoliko se bude delovalo preventivnim merama na socijalne faktore koji dovode do ulaska žena u prostituciju, uz istovremeno suzbijanje potražnje za seksualnim uslugama. Podjednako važno je da se država aktivno uključi u rešavanje problema prostitucije u cilju poboljšanja samog položaja žena koje se bave prostitucijom, a koje se može postići prevashodno napuštanjem prevaziđenog prohibicionističkog sistema regulisanja prostitucije.

Do izmene modela zakonskog regulisanja prostitucije u Republici Srbiji kažnjavanje žena u uličnoj prostituciji će i dalje biti glavno merilo efikasnosti kaznene politike u oblasti prostitucije.

\section{LITERATURA}

1. ASTRA, 2011, Trgovina ljudima u Republici Srbiji, Izveštaj za period 2000-2010, (http://www.astra.org.rs/wp-content/uploads/2008/07/palermo-2010-SRP-web. pdf, 15.08.2016).

2. Danna, D., 2014, Report on prostitution laws in the European Union, http://lastradainternational.org/lsidocs/3048-EU-prostitution-laws.pdf, (25.08.2016). 
3. Global report on trafficking in persons, https://www.unodc.org/documents/dataand-analysis/glotip/GLOTIP_2014_full_report.pdf, (15.08.2016).

4. Kuhajda, V., 1972, Prostitucija u Vojvodini, magistarski rad, Pravni fakultet Univerziteta u Beogradu.

5. Nikolić, Z., 2007, Prostitucija i trgovina ljudima, Zbornik Instituta za kriminološka i sociološka istraživanja, 1-2.

6. Radulović, D., 1986, Prostitucija u Jugoslaviji, Beograd.

7. Sexual exploitation and prostitution and its impact on gender equality, http:// www.europarl.europa.eu/RegData/etudes/etudes/join/2014/493040/IPOLFEMM_ET(2014)493040_EN.pdf, (12.08.2016).

8. Stojaković, G., Petrović-Ranitović, T., 2013, Prostitucija u Srbiji: jedno od mogućih lica, Novi Sad.

9. The human cost of 'crushing' the market, criminalization of sex work in Norway, http://www.amnestyusa.org/sites/default/files/norway_report_-_sex_workers_ rights_-_embargoed_-_final.pdf, (31.08.2016).

10. Žikić, B., 2008, Rizik i nasilje, Antropološko proučavanje seksualnog rada u Beogra$d u$, Beograd.

\section{PRAVNI IZVORI}

1. Convention for the Suppression of the Traffic in Persons and of the Exploitation of the Prostitution of Others (http://www.ohchr.org/EN/ProfessionalInterest/Pages/TrafficInPersons.aspx, 15.05.2016).

2. Declaration on the Elimination of Violence against Women, (http://www.un.org/ documents/ga/res/48/a48r104.htm, 31.08.2016).

3. Directive 2011/36/EU of the European Parliament and of the Council of 5 April 2011 on preventing and combating trafficking in human beings and protecting its victims, and replacing Council Framework Decision 2002/629/JHA, (http:// eur-lex.europa.eu/legal-content/EN/TXT/PDF/?uri=CELEX:32011L0036\&from= EN, 31.08.2016).

4. European Parliament resolution on strategies to prevent the trafficking of women and children who are vulnerable to sexual exploitation (2004/2216(INI)), (http:// www.europarl.europa.eu/sides/getDoc.do?pubRef=-//EP//TEXT+TA+P6-TA2006-0005+0+DOC+XML+V0//EN, 31.08.2016).

5. European Parliament resolution on the current situation in combating violence against women and any future action (2004/2220(INI)), (http://www. europarl.europa.eu/sides/getDoc.do?pubRef=-//EP//TEXT+TA+P6-TA-20060038+0+DOC+XML+V0//EN, 15.08.2016).

6. Konvencija Saveta Evrope o borbi protiv trgovine ljudima, Sl. glasnik RS-Međunarodni ugovori, br. 19/2009.

7. Krivični zakonik, Sl. glasnik RS, br. 85/05, 88/05 - isp., 72/2009, 111/09, 121/12, 104/13 i 108/14.

8. Predlog zakona o prekršajima protiv javnog reda i mira Republike Hrvatske, (www.sabor.hr/fgs.axd?id=21935, 18.08.2016). 
9. Recommendation 1325 (1997) Traffic in women and forced prostitution in Council of Europe member states, (http://assembly.coe.int/nw/xml/XRef/XrefXML2HTML-en.asp?fileid=15359\&lang=en, 31.08.2016).

10. Recommendation No. R(2000)11 of the Committee of Ministers to member states on action against trafficking in human beings for the purpose of sexual exploitation, (http://polis.osce.org/library/f/2686/499/CoE-FRA-RPT-2686-ENCouncil\%20of\%20Europe\%20Committee\%20of\%20Ministers\%20Recommendation\%20R(2000)\%2011.pdf, 31.08.2016).

11. Zakon o javnom redu i miru, Sl. glasnik RS, br. 6/16.

12. Zakon o potvrđivanju Fakultativnog protokola o prodaji dece, dečijoj prostituciji i dečijoj pornografiji uz Konvenciju o pravima deteta, Sl. list SRJ - Međunarodni ugovori, br. $7 / 02$.

13. Zakon o potvrđivanju Konvencije Ujedinjenih nacija protiv transnacionalnog organizovanog kriminala i dopunskih protokola, Sl. list SRJ - Medunarodni ugovori, br. $6 / 01$.

14. Zakon o javnom redu i miru, Sl. glasnik RS, br. 51/92, 53/93, 67/93, 48/94, 101/05 - dr. zakon i 85/05 - dr. zakon.

\title{
PROSTITUTION IN COMPARATIVE LAW AND THE LAW OF THE REPUBLIC OF SERBIA
}

\author{
Dragana Pejović
}

\section{SUMMARY}

In the year 2016 Law on Public Order and Peace came into effect which brought innovations when it comes to the regulation of the prostitution in the Republic of Serbia. Specifically, in addition to the people who indulge in prostitution, which are mostly women, this Law prescribes punishment of misdemeanor for prostitution service users. The subject of the analysis in this paper is the legal regulation of the prostitution in the Republic of Serbia. It will analyze the provisions of the Law on Public Order and Peace which regulate prostitution, as well as provisions of international documents that are relevant when it comes to the regulation of the prostitution, by applying the normative methods. Given the fact that the international documents designate the demand for commercial sex acts as the main factor which has influence on the growth of the prostitution, comparative analysis will provide an insight into whether the Republic of Serbia has legally effective solution in the field of the prostitution which has effect on the decreasing the demand. The main goal of this research is to determine whether the Republic of Serbia has regulated prostitution in accordance with international documents and current models of legal regulation of prostitution in member states of the $\mathrm{EU}$ that have results 
in the suppression of the prostitution. The results of the research showed that the Republic of Serbia still has prohibition model of regulation which is almost completely abandoned because of the inefficiency in the field of the suppression of the prostitution, and which repressive measures mostly affect women in prostitution. Effective results in the field of the suppression of the prostitution can only be achieved by modifying existing models in such a manner so that the measures against the prostitution will be directed towards the users who form the demand for prostitution.

Key words: international documents, prostitution, Law on Public order and Peace of the Republic of Serbia, the legal regulation of the prostitution, women in prostitution.

Dostavljeno Redakciji: 31. oktobra 2016. god.

Prihvaćeno za objavljivanje: 20. decembra 2016. god. 